\title{
SEMIOTICS PROGRESS IN TRADITIONAL-GAME-BASED NUMBER LEARNING FOR PRIMARY SCHOOL STUDENTS
}

\author{
Nasrullah \\ FMIPA Universitas Negeri Makassar \\ email: nasrullah@unm.ac.id
}

\begin{abstract}
This study was aimed at describing the students' semiotic progress on learning number by using traditional games of Bermain Satu Rumah (BSR) supported by a set of learning activities based on Indonesian Realistic Mathematics Education. The study was designed into three stages, that is, the preliminary design, the teaching experiment, and the retrospective analysis. Then, Hypothetical Learning Trajectory (HLT) was modified as the reference of this study as well as the research instrument. HLT was tested to 24 third graders. The data were collected by applying the interview technique, observation, and field notes. The findings of the study showed that this instructional design could motivate students to join learning activities and could stimulate them to conserve the context, to understand the symbol meaning and use it, and to communicate starting from the informal to the formal levels. The progress was on the ability of students to abstract by holding and using symbols as a part of plan to solve the problem.
\end{abstract}

Keywords: semiotics, bermain satu rumah, hypothetical learning trajectory, learning numbers

\section{KEMAJUAN SEMIOTIKA DALAM PEMBELAJARAN BILANGAN BERBASIS PERMAINAN TRADISIONAL BAGI SISWA SEKOLAH DASAR}

\begin{abstract}
Abstrak: Penelitian ini bertujuan untuk mendeskripsikan kemajuan semiotika siswa dalam pembelajaran bilangan dengan menggunakan permainan tradisional Bermain Satu Rumah yang didukung dengan serangkaian aktivitas belajar berdasarkan Pendidikan Matematika Realistik Indonesia. Penelitian didesain melalui tiga fase, yaitu desain awal, eksperimen mengajar, dan analisis retrospektif. Dugaan Lintasan Belajar dibuat sebagai acuan dalam pelaksanaan penelitian sekaligus menjadi instrumen penelitian. Dugaan Lintasan Belajar diujikan kepada 24 orang siswa kelas III SD. Pengumpulan data dilakukan dengan menggunakan teknik wawancara, pengamatan, dan catatan lapangan. Hasil penelitian menunjukkan desain pembelajaran ini dapat memotivasi siswa untuk mengikuti kegiatan pembelajaran dan dapat merangsang siswa untuk mengonservasi konteks, memahami makna simbol dan menggunakannya, serta mengomunikasikan mulai dari tahap informal sampai formal. Kemajuan yang ditemukan adalah kemampuan siswa untuk mengabstraksi dengan mengadakan dan menggunakan simbol sebagai bagian dari rencana untuk menyelesaikan masalah.
\end{abstract}

Kata Kunci: semiotik, bermain satu rumah, dugaan lintasan belajar, pembelajaran bilangan

\section{INTRODUCTION}

Numbers is one of the three aspects contained in Kurikulum Tingkat Satuan Pendidikan (KTSP) as a reference of education in Indonesia. In addition to numbers, aspects of geometry, measurement, and data processing (statistics) are other aspects which are also considered in the curriculum. Learning numbers for prima- ry school level is being important for learning other subjects (Freudenthal, 1973; NCTM, 2000), learning numbers tend to form an understanding of notation, symbols, and other shapes that represent so as to support the thinking and understanding of the children to solve their problems (NCTM, 2000). Therefore, learning becomes 
number one prerequisite knowledge for learning other topics in mathematics.

Counting activity encourages students to develop an understanding of numbers siswa. Reys \& Yang (1998) suggested that knowledge of numbers shows the person's general knowledge about the numbers and operations. Understanding of numbers and operations to be very important for students based on a conceptual framework that is structured on the information numbers so as to enable a person to understand the numbers and the link numbers and to solve mathematical problems that are not limited by the algorithms of traditional (Bobis, 1996, YeaLing Tsao, 2004). Understanding of numbers can be divided into five components that characterize, ie to understand numbers, relation numbers, the amount of numbers, operations that involve numbers, and symbols for numbers and quantity.

Semiotics in mathematics is the use of symbols that are useful in understanding the process of thinking, symbolizes and communicates (Radford, Schubring, and Seeger, 2008; Ostler, 2011). Semiotics in the teaching of mathematics in particular shows the teaching of mathematics as a process of manipulation of symbols through structured algorithms and by strictly defining theorem.

It was interesting mentally for a symbol because it is not easy to do if you do not understand the symbolization of symbols used and what the intended use. Relation to the traditional games used in this study is the power of symbolism itself. Relies on the power of mathematical symbols, before we can communicate knowledge including mathematics, the ideas contained in the memory or the owner thought the idea should be attached together with the symbol (Skemp, 1989).

Indonesian children have fun with traditional plays. As example, primary school children in the area of Southeast Sulawesi fond of playing satu rumah game, then the game is played in a school break, known to come out to play. Uniquely, this game is also played in the area of Palembang. Although his name is not clear (anonymous), the respondent (citizens of
Palembang) interviewed said that around 1993 this game to be one type of game that favored the students of SDN 64 Palembang (now, SDN 1 Palembang). Traditional games based learning means using traditional games as a context for learning. The use of contexts is a medium that is expected to help students to establish the concept of learning and developing the concept (Zulkardi, 2002) The game traditionally is a local phenomenon, the potential/local phenomenon serves as a source of learning. It was not unlike the case with the people who use the Dieng plateau local phenomena community as a learning resource (Suratsih, dkk., 2009).

Wijaya (2008) conducted a study to design a study that involves the game of marbles and benthik (patok lele) for linear measurement concept, the results revealed that the students understand the idea of transitivity and indirect comparisons.

Based on observations that have been made, the Treffers's question (Streefland, 1991) be interesting to study the teaching of arithmetic acoustic, synchronous and resultative. $\mathrm{He}$ assumed that although children can count many numbers of 1-digit and 2-digit, does not guarantee them a right to understand the basic concepts of arithmetic synchronous and resultative. In other words, the main problem that occurs is the understanding of the numbers.

If this understanding should be established by using the context of the traditional games, such as what is formed as an understanding of the concept of numbers. Ostler (2011) found the smooth procedure as outcomes of learning and teaching strategies, but semiotics promoted by applying traditional games especially learning numbers.

Traditional games are used as a context for learning is called Bermain Satu Rumah (BSR). The game is widely used elementary school students in the city of Kendari, Southeast Sulawesi. Sut-sutan activity is then represented in the image of the rumah into a context that is applied as a starting point for a number of learning activities.

The use of the phenomenon as a learning resource means using traditional game satu 
rumah as a learning resource. Students will form the concept possessed mathematics learning by using the phenomenon of bermain satu rumah.

This is in line with one of the principles in realistic mathematics education, namely didactical phenomenology. Therefore, semiotics processing activities in a number of learning are applied in mathematics learning activities involving realistic mathematics approach. The intended processing will occur through mathematical processes, as in PMRI are two mathematizations, ie horizontal and vertical.

In addition to mental computation involved in mathematical processes, numbers sensitivity is also required with the involvement of number sense. To that end, the image constructed rumah is expected to be interpreted as numbers or numbers, before they are used in arithmetic-resultative operations.

To support this paper, the research activities focused on semiotics component which consists of understanding the process of thinking, symbolizes and communicates. Thus, semiotics processing referred to in this article is a learning process that is built student involving three activities, namely the understanding of the process of processing the information obtained, then represented by a symbol which is considered representative, and communicate knowledge that is being built.

Widjaja, Dolk and Fauzan (2010:168) found that a meaningful context supports the idea and understanding of users. The existence of BSR game into a medium that can be applied to support the learning process with a game of numbers which will support students' understanding associated with numbers.

To support the understanding of numbers, in addition to number sense and mental arithmetic that has formed in the scheme of student thinking, they also need to know the devices they use in constructing an analysis of the problems that wants to be solved. For example, to encourage students to use the literacy numbers in a game against the tool that represents a number. As we know sut-sutan which will then be shown in the picture is evidence that already at the stage of what they accomplished and the wins that have been achieved.

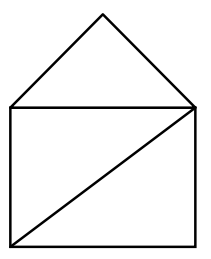

(a)

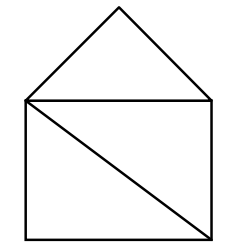

(b)

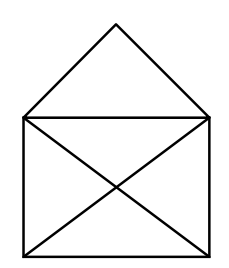

(c)

\section{Figure 1. Examples of Rumahs Being Played}

As shown in Figure 1, to determine whether the player can build a new rumah after can fill with a diagonal line. If the rumah has been filled with a diagonal line, it means the player has qualified to be able to build new rumahs. Therefore, it takes win after winning to build a rumah as much as possible. In other words, many rumah means having a lot of wins. Speaking about a lot of is related to numbers. On this basis, BSR play can be developed for learning numbers.

Specifically in the BSR game-based learning numbers, semiotics student's ability to convert what was obtained from the play. By applying PMRI approach in the learning activities are carried out, there are four levels were observed to support the advancement of semiotics students. Gravemeijer (2010: 40) argues that the four levels are situational, models-of, modelfor, and formal.

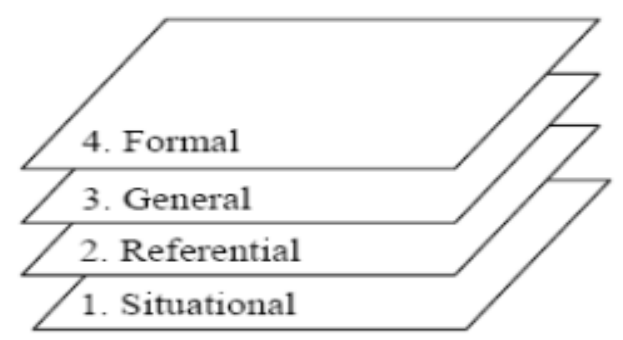

\section{Figure 2. Modelling Levels in PMRI Learning}

Situational level: basic level that raises situational knowledge and strategies used in conjunction context situation. Level referential: the use of a model and strategy at this level indicates the situation described in the problem, 
referential level is level model from. General level: models to emerge in the form of mathematical knowledge with a focus on strategy issues dominate the referral context. Formal Level: reasoning with conventional symbolization did not take long to support the activity in case the mathematical model for. The focus of the discussion develops on the characteristics of the model related to the concept of addition, subtraction, and multiplication.

\section{METHOD}

Research design was chosen as the research method. There are three phases through which to carry out this study, the preliminary design stage, teaching experiment, and a retrospective analysis (Gravemeijer \& Cobb, 2006: 19).

As the first step, hypothetical learning trajectory (HLT) has been designed. Apart from being an instrument, HLT is made as a reference learning preparation. In order to the equipment of experimental teaching can take place properly and as intended, teachers and observers using HLT during the implementation of teaching, interviews, and observations. At the end of the research activities of design, a retrospective analysis applied with reference to the HLT (Bakker, 2004; Syahputra, 2013).

Subjects involved are teachers and students of class III SD Inpres Mallengkeri I Makassar. More specifically, the third grade students of 30 people and a teacher who taught in the class. For the initial design, 6 students selected to take part in the beginning of the study. Furthermore, the next 24 students involved in the experiment teaching. To get the data, interviews were conducted with teachers and students and is equipped with an observation that generate field notes and student activity sheets. Once the data is collected and analyzed, the findings and conclusions made note of the study to answer the research question.

To track the progress of students in learning numbers semiotics, three ongoing activities designed for each meeting. HLT designed in this study were divided into a number of meetings as follows.
Lesson I : Play rumah sut-sutan

Activity 1 : Play Satu Rumah

Objective : Understand the rules of the game, game procedures.

Activity 2 : Conserve the win into a number, reference number and the numbers determine numerosity, determine resultative counting.

Objective : Understand the context, symbolize the figure, specify the reference number and numerosity, and determine resultative counting.

Lesson II : Counting Wins

Activity 3 : Conserve win into a number, determine reference number and numerosity number, determine resultative counting

Objective : Understand the context, symbolize the figure, determine reference number and numerosity number, and determine resultative counting.

\section{RESULT AND DISCUSSION}

For the first activity, students are introduced to this type of game following the rules and procedures applicable game. Once they know all too well, as development activities, the second activity in which the activities carried out is to conserve the crossed line into a number, specify the reference numbers and the number of numerosity. Conservation meant in this case is the ability to realize that behind the lines can be measured with numbers (Reys, Suydam, and Lindquist, 1984). To be determined that the lines of the numbers, awareness must be raised about the number that can represent any wins obtained in the form of a reference number and the number of numerosity. Freudhental (1973) states that the reference number is the number that determines the beginning of the next number as a representation of counting activities, while the number numerosity is the whole number, which measures how many the object of counting. To that end, numerosity numbers can be used in determining the resultative number. 
The trajectory of student learning by learning to use the game BSR numbers can be shown in Figure 3.

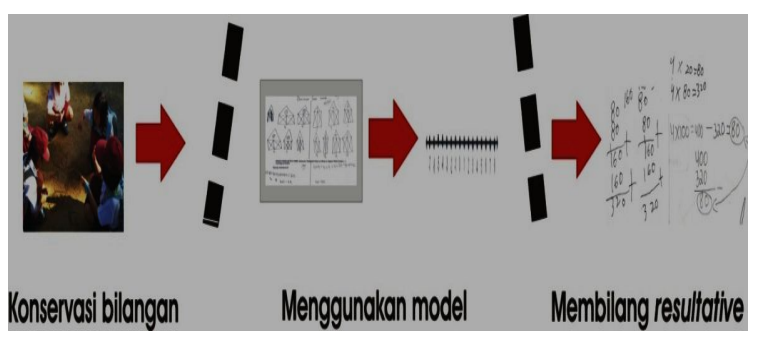

Figure 3. Learning Trajectory Based Play Rumah Sut-sutan

Figure 3 divides three stages that take place when students are engaged in learning numbers on the basis of this game, namely the conservation of numbers, using the model of the unit, and resultative counting.

Number conservation is an important activity to explore what children know about numbers. Moreover, children should explore a number that reflects how they think. It emphasizes the importance to be aware of the symptoms of the weakness of conservation and its impact for the initial number (Reys, Suydam, and Lindquist, 1984). Conservation numbers help the formation of basic skills numeracy; therefore empowered conservation activities in traditional games used as learning early numbers for third grade students. The context of the game such as playing rumah sut-sutan can be used to direct students to understand the concept of numbers numerosity and significance of counting non-standard basis. Recognize the rumah and the number line through play activities is one way in a number of conservation.

Conservation of numbers that lead to the game is to identify what the model number can be calculated. Crossed the line and the rumah number is the model where students can determine how many wins they earn from rumah after playing. The question of "how much" leads to the cardinal numbers, the target is a reference number and numerosity. At level model-of, figures are used as rumah with intersecting lines and numbers to discover a way of thinking students in math. If students have gained numbers in this game combined with critical questions to explore an understanding of numbers, they should apply their reasoning to work on math problems given. Hopefully, counting resultative will be directed to support their mental arithmetic.

Figure rumah as a representation of the number is expected to serve as the student works with a number line as a model in the counting procedure. Numbers based rumah has similarities with the pattern number line making it possible to make a correspondence 1 - 1 . In addition, students draw up numbers on a line starting from the raw instrument does not count toward the number line as a raw count instrument. As a result, students must determine the sequence of numbers on a number line based on knowledge of counting and numbers numerosity. So, to complete the number line is not complete when assessing the student must perform resultative counting with the linking of counting to the number numerosity.

Resultative counting, one of the benefits Davydov procedure is to assist the development of counting resultative by connecting the count to the number numerosity. It is hoped that students can add and subtract because they are able to count resultative. Theoretically, the structure of learning (Gravemeijer, 1994) is a learning model numbers can be directed researchers to determine the learning path so that the knowledge of mathematical concepts, addition and multiplication, and subtraction, students can be involved in their daily activities.

After playing activity lasted for a few minutes, the results obtained are shown in Figure 4.

Results from the game BSR, as shown in figure 4 shows the two players who managed to build their rumah. As it is known that the rumah contains four diagonal lines intersect. In other words, four wins in a sut-sutan to build one rumah. To redirect the focus of this research, the semiotic elements that can be developed by students in learning activities. There are two questions that are charged to students, the core of both of these questions is a win obtained and many rumahs that can be formed. 


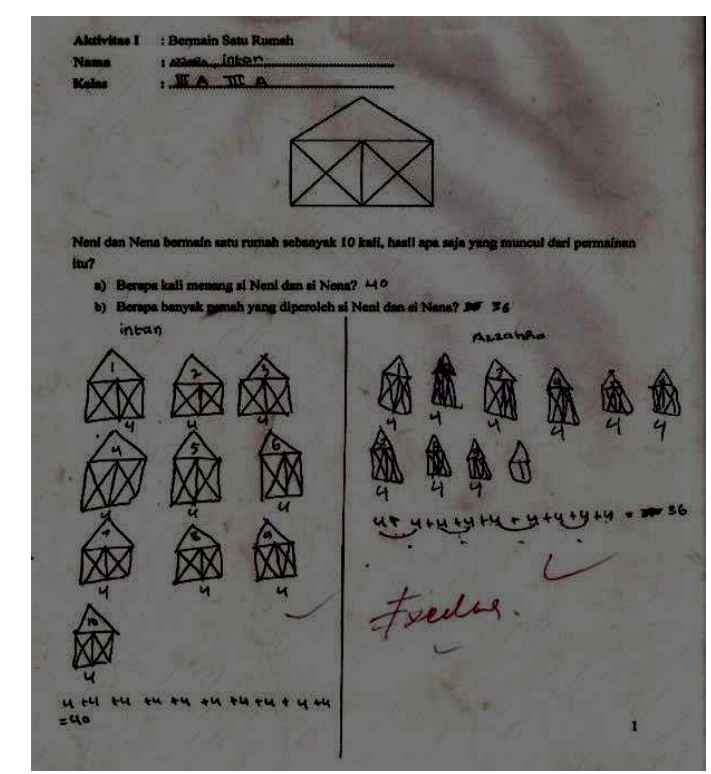

Figure 4. an Example of Result Game BSR

To show the correct answer on the first question, the student 1 (player 1) symbolizing each rumah with the number 4 . Meanwhile, students 2 (2 players) also do the same. Researchers believe that meaning of wins in the form of intersecting diagonal lines are the numbers. If in one rumah contains four diagonal lines can be interpreted 4 wins, then the answer to the question many wins equals 4 . So, the number 4 is the result of the conservation of many diagonal lines or the number of wins. Because of the various wins achieved as indicated by the rumahs are built, to calculate how many wins obtained by each rumah given the symbol 4 . For example, one player who managed to build 10 rumahs, then there are ten 4-an operated summation. In line with 2 players, although the $r u$ mah have been built not reach 10. Interestingly, since only 9 rumahs, then a 4's-operated only up to nine as well.

Prior to the conclusion that many wins is 40 , for example, players 1. Each rumah is symbolized by the number 4 as well as a number of reference numbers to satu rumah numerosity. Meanwhile, for as many as 10 rumahs, the symbol evolved into a $4+4+4+4+4+4+4+4$ $+4+4$. In other terms, winning 10 rumahs are equal to the sum of ten 4's. Numerosity one rumah will be changed or increased when it became ten rumahs, because it numerosity ten rumahs is 40 . Similarly, the second player, reach- ing only nine rumahs evolved into a symbol so that the $4+4+4+4+4+4+4+4+4$ or nine 4 's. For this reason, the numerosity of nine $r u$ mahs is 36 , and the second player is declared the loser.

Interestingly, semiotic processes occurring in BSR's activities are divided into 3 stages. First, the conservation of the many wins are the symbols of the numbers, for example, 4 is the fact a win for the rumah being built. Secondly, symbolizing the reference number 4 as well as the number numerosity any rumah or around the rumah to declare many wins. Third, the use of symbolization with 4 restricted by many rumah or many wins achieved and the reason is to determine who the winner in this game is.

As the target of the execution of this study is what semiotics progress can be demonstrated by the student in learning activities. To accomplish this, the activity did not differ goal with the first activity, but coupled with determining the outcome number of resultative counting. Actually, numerosity numbers can be numbers the result of the operation. In other words, lots of wins is 40 or 36 is the number of results. But not only is it being targeted by administering 2 activities, but the techniques used to obtain the number.

By using the context of the problems that are still associated with BSR, assuming the rules and procedures that have been formed in the scheme of thinking students then developed as a teaching material. For example, previous students who managed to build one, two, or four rumahs, even more than that. Furthermore, what if a game ends after one reaches the four rumahs, then the question is how much it takes to win it?

Various of answers can be shown to students in these activities. One of them is the answer of Shafira and Nabila which is used to determine win not only by multiplying (using the concept of multiplication), but also add up (using the concept of summation). By abstracting the rumahs are made of students as a result of the game BSR where abstraction is meant in this case is to build assuming similarity of the object in question (Mitchelmore \& Hassan, 
2004). Therefore, what will be shown students in this conservation of context are the target of activity II.
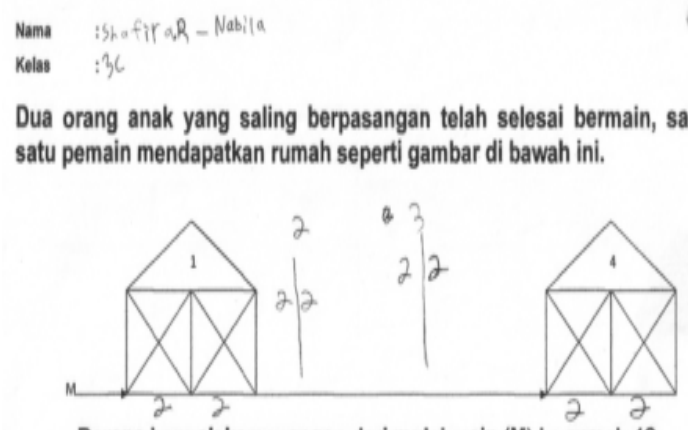

Berapa banyak kemenangan dari mulai main (M) ke rumah 4 ?

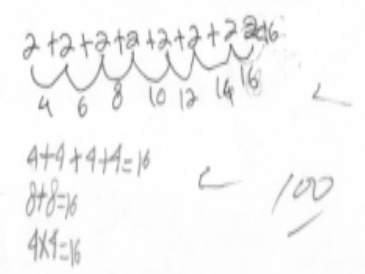

Figure 5. An Example of Student Work in Activity II

As a result that looks like in Figure 5, semiotics process takes place in three stages, the first is conservation. Because of the problems discussed in the win were given, each diagonal line formed as a result of playing a given symbol. By other terms, the conservation of the diagonal line is conservation of many wins, how much is indicated by the symbol.

The second is symbolization. Each diagonal lines that existed at rumah represented with numbers, such as "2" .So also between rumah 1 and rumah 4, students add an empty space with the symbol "2|2" which means that rumah has two diagonal lines the left and right.

Lastly is communication. Essentially there are two concepts that are given to explain that many wins achieved were 16 .

The first concept by using summation where wins in a rumah containing composition 2 (left) and 2 (right), then the students write down the $2+2+2+2+2+2+2+2=16$. Another form is $4+4+4+4=16$, assuming that the rumah has 4 wins. They also wrote $8+$ $8=16$, by accumulating two 4 's. The next concept, he said because there are 4 rumahs and each rumah contains 4 wins, means $4 \times 4=16$.
Here is picking dialog students and teachers about the response in the figure 5.

\section{Dialog for answers of figure 5}

Guru : where it does, where the 4's come from?

Nabila : (while pointing crossed lines)

Guru : the wins, then it is added four again, where this four come from?

Shafira : (while pointing crossed lines onto $r u$ mah)

Guru : then this one?

Shafira: (while pointing writing number 2 illustrated as crossed lines in the second rumah)

Guru : this one?

Shafira: (while pointing writing number 2 illustrated as crossed lines in the third rumah)

Guru : this one?

Shafira: (while pointing writing number 2 illustrated as crossed lines in the fourth rumah)

Guru : let find the sum at all, what is it?

Nabila : (while write the answers on her worksheet)

Guru : Yo, how come, how many this, like that ya!

Nabila : four added by four, eight, eight added by four, twelve, twelve added by four, sixteen

Guru : yes the same, so similar ways, ya! Excellent

When the activity 3 in which abstraction increased compared to activity 2 , it is done by raising concerns as shown in Figure 5.

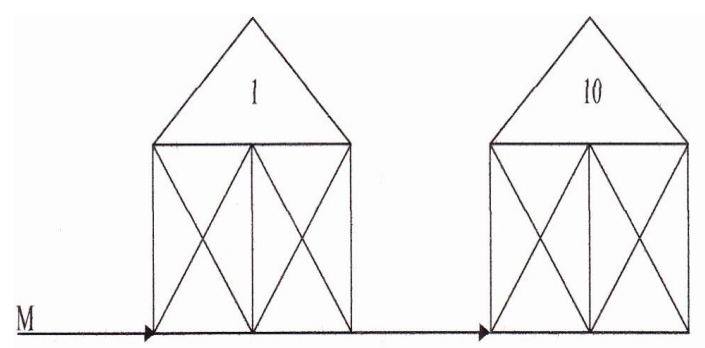

Berapa banvak kemenangan dari mulai main (M) ke rumah 10 ? 
Figure 6. An Example of Problem Activity 3

By giving the problem as shown in figure 6 above, which is intended abstraction of this problem is the students are asked to think of many wins in case after playing reached $10 \mathrm{ru}$ mahs. By not writing all these rumahs, they are expected to be able to determine many of the crossed lines. One of the students' answers is shown in figure 7 .

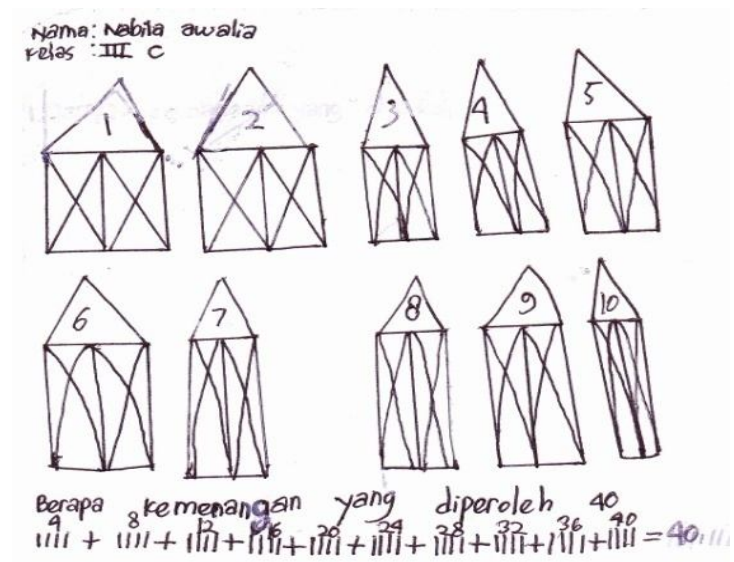

Figure 7. An Example of Student Work in Activity 3

As seen from this picture is any diagonal lines in the picture rumahs are represented by lines pillar before symbolized into figures, this is an example of conservation diagonal line on the game BSR. Before the students stated many wins, the rumah consists of four lines so that ten rumahs containing 10 four-line associated with the addition operation. Because the arithmetic can not take place spontaneously, the student is doing summation resultatif partially, 4 and 8,12 , grew 4 to 16 , plus 4 equals 20,21 , $22,23,24$ at rumah to the $6^{\text {th }}, 28^{\text {th }}$ rumah to -7 , 32 rumah-to- 8 . To arrive at the calculation of 36 , the student must be counting again by calling $33,34,35,36$. To reach the final effort to determine that many wins at rumah to $10^{\text {th }}$ is 40.

\section{Dialog for answers of figure 7}

Guru : why its rumah is ten, you know only rumah 1 and rumah 10 ?
Nabila : this one starting from rumah 1 to $r u$ mah 10 (while pointing figure rumah in the problem)

Guru : why there are four lines, what for?

Shafira : I think these lines in this rumah are any four (while pointing crossed line in the rumah)

Guru : you mean this line, this one?

Shafira : Yes, hmm any four so the lines are four as well (while pointing written lines illustrated as crossed lines in these rumahs)

Guru : hmm like that, why any addition sign is here, what for, what are you looking for?

Shafira : these wins, you know, fourty, fourty means there are this four lines added with this four lines again, so eight, nine, ten, eleven, twelve, that's why here is twelve.

Guru : then why this is sixteen, twenty, twenty four, twenty eight, thirty, and the last is going to fourty?

Shafira : caused by added with four, until getting fourty.

Guru : Oh these ones are added all, how many?

Nabila : (while write the answers on her worksheet)

Guru : Yo, how come, how many this, like that ya!

Nabila : four added by four, eight, eight added by four, twelve, twelve added by four, sixteen, twenty, twenty four, twenty eight, thirty, thirty two, thirty six, fourty.

Guru : yes the same, so similar ways, ya! Very good

After a conservation process that looks at the image, a symbol is a second stage before performing arithmetic operations with addition. "Tally" and the figures are part of many wins symbolized at once communicate a technique used to determine that many of crossed lines was 40 .

By providing two levels of different problems, different semiotic processes also emer- 
ged from both. Differences semiotic processes between activity I and both of activities II and III show that in demonstrating the answers they've been able to show two capabilities. First, conservation of daily contexts into a mathematical form becomes more interesting into learning numbers, and symbolization. Interestingly, the use of the symbol "2|2" to complete rumahs that are not raised a creative effort a student. Similarly, in the third activity, where students have held eight rumahs were not raised to complete ten rumahs were discussed. Win in these rumahs can also be converted into figures to explain the many wins achieved in the context of the game.

\section{CONCLUSION}

Semiotics progress which is intended as the student's ability to conserve the context of the traditional game into a mathematical model, using symbols to support the construction plan problem solving, and communicating those ideas so that a given problem can be solved.

The progress of conservation ability is in the form of identifying diagonal line on the game BSR as winning signs, to understand the meaning of symbols, associated with many wins, and involves mathematical concepts such as arithmetic operations to solve a given problem, and can be explained by variations completion to determine the many wins of the results of play.

The process of abstraction shows that the students have the ability to hold and use the symbol as part of a plan to do problem solving. The success of this study indicates that the traditional game play of the rumah can also be used as a medium of learning. Thus, once a local phenomenon in the culture of the community can be used as a meaningful learning.

\section{ACKNOWLEDGEMENT}

The author thanks for Lembaga Penelitian UNM upon research grant of PNBP FMIPA to support institutional research project. Similarly, thanks are also extended to reviewers, and the editor of the Journal Cakrawala Pendidikan who have given chance to publish this article.

\section{REFERENCES}

Bakker, A. 2004. In Design Research in Statistics Education on Symbolizing and Computer Tools. Amersfoort: Wilco Press.

Bobis, J. 1996. "Visualisation and the Development of Pemahaman Bilangan with Kindergarten Children". In Mulligan, J. \& Mitchelmore, M. (Eds.) Children's Number Learning: A Research Monograph of the Mathematics Education Group of Australasia and the Australian Association of Mathematics Gurus. Adelaide: AAMT.

Freudenthal, H. 1973. Mathematics as an Educational Task. Dordrecht, the Netherlands: Kluwer Academic Publishers.

Gravemeijer, K. 2010. Realistic Mathematics Education Theory as a Guideline for Problem-Centered, Interactive Mathematics Education. In K. H. Robert Sembiring (Ed.), A Decade of PMRI in Indonesia (pp. 41-50). Bandung, Utrecht: Ten Brink, Meppel.

Gravemeijer, K. and Cobb, P. 2006. Design Research from the Learning Design Perspective.In Van den Akker, J., Gravemeijer, K., McKenney, S., \& Nieveen, N. (eds.). Educational Design Research. London: Routledge.

Gravemeijer, K. 1994. Developing Realistic Mathematics Education. Utrecht: Technipress, Culemborg.

Mitchelmore M., \& Hassan I. 2006. The Role of Abstraction in Learning about Rates of Change. Proceedings of the 29th annual conference of the Mathematics Education Research Group of Australasia, Canberra pg. 278 - 285. Adelaide: MERGA.

National Council of Teachers of Mathematics 2000. Principles and Standards for School Mathematics. Reston, VA: National Council of Teachers of Mathematics. 
Ostler, E. 2011. Teaching Adaptive and Strategic Reasoning Through Formula Derivation: Beyond Formal Semiotics. International Journal of Mathematics Science Education, Vol. 4, No. 2, pp. 16 - 26.

Radford, L., Schubring, G., \& Seeger, F. 2008. Semiotics in Mathematics Education: Epistemology, History, Classroom, and Culture. Sense Publishers: Rotterdam/ Taipei.

Reys, Robert E., Suydam, Marilyn N., \& Lindquist, Mary M. 1984. Helping Children Learn Mathematics. London: PrenticeHall International.

Skemp, R., 1989. Mathematics in The Primary School. London: Routledge.

Streefland, L., 1991. Fractions in Realistic Mathematics Education. A Paradigm of Developmental Research. Dordrecht: Kluwer Academic Publishers.

Suratsih, Henuhili, V., Rahayu T., \& Hidayat M. L. 2009. "Pengembangan Modul Pembelajaran Genetika Berbasis Fenomena Lokal". Cakrawala Pendidikan, Juni 2009, Th. XXVIII, No. 2.

Syahputra, Edi. 2013. "Peningkatan Kemampuan Spasial Siswa melalui Penerapan Pem- belajaran Matematika Realistik". Cakrawala Pendidikan, November 2013, Th. XXXII, No. 3, hlm. 365.

Widjaja, W., Dolk, M., \& Fauzan, A. 2010. The Role of Contexts and Teacher's Questioning to Enhance Students' Thinking." Journal of Science and Mathematics Education in Southeast Asia, 33(2), hlm.168186.

Wijaya, Ariyadi. 2008. "Design Research in Matematics Education: Indonesian Traditional Games as Means to Support Second Graders' Learning of Linear Measurement". Thesis. Utrecht University. The Netherland: Utrecht University.

Yea-Ling Tsao. 2004. "Exploring the Connections among Number Sense, Mental Computation Performance, and the Written Computation Performance of Elementary Preservice School Teachers". Journal of College Teaching \& Learning. Volume 1, Number 12, December 2004.

Zulkardi, 2002. "Developing a Learning Environment on Realistic Mathematics Education for Indonesia Students Teachers". Thesis. University of Twente. Netherland. 